\title{
EMOTION FOCUSED COPING DALAM MEREDUKSI KECEMASAN PADA MASA PANDEMI COVID-19
}

\author{
Syaiful Indra ${ }^{1}$ Dian Ayuningtiyas ${ }^{2}$ Rizky Andana Pohan ${ }^{3}$ \\ Universitas Islam Negeri Ar-Raniry Banda Aceh ${ }^{1}$ \\ Email: syaifulindra37@gmail.com \\ Sekolah Tinggi Islam Negeri Teungku Derundeng Meulaboh ${ }^{2}$ \\ Email: ayuningtiyasdian@gmail.com \\ Institut Agama Negeri Cot Zawiya Kala Langsa ${ }^{3}$ \\ Email: andanarizkypohan@ gmail.com
}

\begin{abstract}
ABSTRAK
Pandemi Covid-19 membuat tatanan kehidupan manusia terganggu akan kedatangannya. Dampak yang ditimbulkan oleh pandemi covid-19 memaksa individu dalam bersikap adaptif pada kondisi psikologis. Berbagai persoalan psikologis muncul akibat pandemi covid-19, tidak semua individu mampu bertahan dengan kondisi yang baik. Fenomenanya tidak semua individu memiliki kemampuan resiliensi yang memadai, sehingga akan berdampak pula pada kecemasan. Kecemasan akan timbul apabila ada peristiwa buruk yang dialami oleh individu yang belum terselesaikan. Gangguan psikologis yang muncul disebabkan oleh kecemasan dapat terefleksi pada behavior, kognitif, dan fisik. Oleh sebab itu kecemasan sepatutnya perlu adanya penangan atau terapi khusus untuk mereduksi dampak yang muncul. Salah satu variabel yang dapat mereduksi kecemasan adalah emotion focused coping. Emotion focused coping merupakan suatu tindakan untuk mengurangi tekanan psikologis yang muncul oleh stressor. Naskah ini akan mendeskripsikan emotion focused coping dalam mereduksi kecemasan pada masa pandemi covid-19.
\end{abstract}

\section{Kata Kunci: Emotion focused coping, Kecemasan, Covid-19, Konseling}

\section{EMOTION FOCUSED COPING TO INDUCE ANXIENTY DURING THE PANDEMIC COVID - 19}

\begin{abstract}
The Covid-19 pandemic has disturbed the order of human life at its arrival. The impact caused by the Covid-19 pandemic forces individuals to be adaptive to psychological conditions. Various psychological problems arise due to the Covid19 pandemic, not all individuals are able to survive in good conditions. The phenomenon is that not all individuals have adequate resilience abilities, so that it will also have an impact on anxiety. Anxiety will arise if there are bad events experienced by individuals that have not been resolved. Psychological disorders that arise due to anxiety can be reflected in behavior, cognitive, and physical. Therefore, anxiety should have a special treatment or therapy to reduce the impact that appears. One of the variables that can reduce anxiety is emotion focused coping. Emotion focused coping is an action to reduce the psychological
\end{abstract}


pressure caused by stressors. This text will describe emotion focused coping in reducing anxiety during the Covid-19 pandemic.

\section{Keywords:Emotion focused coping, Worry, Covid-19, Counseling}

\section{PENDAHULUAN}

Wabah Virus Corona 2019 (COVID-19) disebabkan oleh Akut Parah Respiratory Syndrome Coronavirus 2 (SARS-CoV-2) pada akhir tahun $2019 \mathrm{di}$ Wuhan, Provinsi Hubei, Cina telah menjadi masalah kesehatan masyarakat yang utama di Cina bahkan secara global (Jiang, Broome, \& Ning, 2020). Pasien penyebab diidentifikasi dari sampel usap tenggorokan yang dilakukan oleh Pusat Pengendalian dan Pencegahan Penyakit di China pada 7 Januari 2020, dan kemudian dinamai Severe Acute Respiratory Syndrome Coronavirus 2 (SARSCoV-2). Penyakit itu diberi nama COVID-19 oleh Organisasi Kesehatan Dunia (WHO) (Sohrabi et al., 2020). Global pandemi covid-19 juga melanda Indonesia, jumlah kasus di Indonesia meningkat dengan pesat, hingga Juni 2020 sebanyak 31.186 kasus terkonfirmasi dan 1851 kasus meninggal (Putri, 2020).

Global pandemi covid-19 ini menyebabkan berbagai persoalan yang menggangu dan merusak tataran kehidupan manusia. Sendi-sendi kehidupan yang dapat terganggu diantaranya pada sektor kesehatan, sosial, pendidikan, ekonomi dan psikologis. Tataran kehidupan manusia mulai berubah seiring bertambahnya jumlah orang yang terpapar dan meninggal dunia, sekolah mulai ditutup sehingga pembelajaran secara daring, ekonomi mengalami resesi, keterbatasan dalam berinteraksi secara langsung, hingga muncul gangguan-gangguan psikologis (Putri, 2020; Syah, 2020; Ulya, 2020).

\section{LANDASAN TEORI}

Sektor kehidupan yang terganggun ini menimbulkan berbagai persoalanpersoalan, ketahanan manusia dalam menghadapi situasi dan kondisi wabah covid-19, sehingga menimbulkan kecemasan bahkan depresi pada diri individu (Mazza et al., 2020). Semua hal ini menciptakan perhatian bagi individu sehingga menyebabkan meningkatnya kecemasan. Pandemi dapat meningkatkan stres; kecemasan merupakan respons umum terhadap situasi stres (Roy et al., 2020). Oleh karena itu, pandemi pada akhir Juni 2020, Covid-19 berkontribusi relative 
dalam sumbangsih pada tekanan psikologis terhadap kecemasan umum dan gejala depresi yang mengendalikan apa sebagai faktor kerentanan utama (Nikčević, Marino, Kolubinski, Leach, \& Spada, 2021). Setiap individu dapat merasakan kecemasan dari waktu ke waktu. Hanya sedikit individu yang berhasil melewatinya masa tanpa ketegangan cemas atau perasaan bahwa sesuatu tidak akan berjalan dengan baik (Rector, Bourdeau, Kitchen, \& Massiah, 2011).

Oleh sebab itu, perlu adanya adanya tindakan konseling dalam mereduksi gangguan kecemasan yang dialami individu agar tidak menggangu keberlangsungan hidup seseorang. Mereduksi gangguan kecemasan memerlukan penanaman coping ablity pada individu. Stressor yang diakibatkan oleh gangguan kecemasan perlu sumber coping yang baik dalam penanganannya. Coping sebagai upaya kognitif dan perilaku yang terus merubah untuk mengelola tuntutan eksternal dan/ atau internal tertentu yang dinilai membebani atau melebihi sumber daya individu tersebut (Richard S. Lazarus \& Susan Folkman, 1984). Salah satu strategi coping yang dapat digunakan dalam mereduksi gangguan kecemasan adalah emotion focused coping. Misalnya terdapat pada terapi doa, berfungsi sebagai penanganan yang berdasarkan emotion focused coping. Penolakan dan reinterpretasi positif keduanya dianggap sebagai penanganan yang juga berfokus pada emosi (emotion focused coping), sementara strategi emotion focused coping lebih mungkin digunakan dalam kondisi yang dinilai sebagai kemampuan pengendalian yang rendah (Wong, Paul T. P., 2006).

\section{METODE PENELITIAN}

Jenis penelitian yang di implementasikan pada penelitian ini adalah kualitatif dengan metode penelitian kepustakaan. Pada penelitian ini, data yang berfokus dan relevan pada kajian emotion focused coping dan kecemasan. Sumber data didapatkan melalui jurnal publikasi ilmiah baik nasional maupun internasional dan buku-buku yang relevan. Teknik pengumpulan data yang dipakai pada penelitian ini adalah dengan cara yaitu; penelaahan kepada jurnal dan buku yang relevan terhadap variabel. Analisis data digunakan melalui proses mendesrkipsikan temuan yang relevan. 


\section{HASIL PENELITIAN DAN PEMBAHASAN}

Covid-19 memengaruhi hampir semua aspek kehidupan masyarakat. Wabah Covid-19 menghambat individu untuk bekerja, mengurangi penghasilan, mengganggu kualitas ibadah, menyebabkan kecemasan, gangguan kesehatan mental dan mental serta mencegah hubungan sosial antar manusia (Sujadi et al., 2020). Dampak yang dapat ditimbulkan oleh kecemasan mengakibatkan emosi tertekan yang berkepanjangan. Kecemasan memiliki kekhasan berupa timbulnya perasaan takut yang tidak jelas dan tidak menyenangkan (Syaiful Indra, 2016). Setiap kali respons menyerang yang disebabkan oleh bahaya, baik nyata atau perseptual, hal itu menyebabkan perubahan dalam tiga "sistem fungsi": cara individu berpikir (kognitif), cara tubuh merasakan dan bekerja (fisik), dan cara bertindak (perilaku) (Rector et al., 2011). Gangguan kecemasan umum terjadi pada individu yang memiliki kecenderungan berfokus pada ancaman di masa depan. Khawatir, perilaku menghindar atau adaptasi perilaku, dan keluhan otonom dan somatik lainnya juga sering terjadi (Kehoe, 2017).

Gangguan kecemasan memiliki karakteristik ketakutan yang berlebihan dan ada kecenderungan perubahan perilaku. Dalam gangguan kecemasan, stimulus, eksternal atau internal, dihasilkan kecemasan yang tidak proporsional yang merupakan sumber intens kesusahan atau gangguan fungsi, yang mencapai puncaknya dalam beberapa masa dan dikaitkan dengan gejala somatik seperti jantung berdebar, berkeringat, gemetar, sesak napas, sensasi tersedak, nyeri dada, mual, pusing, mati rasa, takut gila, atau sekarat (Maina, Mauri, \& Rossi, 2016). Dalam hubungannya dengan biologis dan pengalaman, faktor kognitif dapat mendorong atau menghambat penerimaan belajar, memperburuk predisposisi biologis, dan mempertahankan gejala gangguan kecemasan. Perhatian selektif, bias memori, bias interpretasi (misalnya, kesalahan kognitif negatif) dan bias penilaian adalah empat bentuk luas dari proses kognitif yang mulai mendapatkan perhatian dalam kaitannya dengan gejala kecemasan (Carl F. Weems, 2013). Kecemasan dan kekhawatiran yang meluas yang bertahan setidaknya selama 6 bulan (pada derajat yang tidak sesuai dengan kemungkinan kejadian yang sebenarnya), ketegangan motorik, hiperarousal; banyak pasien mungkin melaporkan merasa cemas sepanjang hidup mereka. Gangguan signifikan dalam 
kehidupan sehari-hari: masalah tidur, sakit kepala, "kegelisahan", mual, otot tegang, dan gemetar atau hot flash sering terjadi; kelelahan dan kesulitan berkonsentrasi dapat menyebabkan kesulitan di tempat kerja atau rumah (Martin, 2003). Sekitar 12-19\% pasien perawatan utama memenuhi kriteria diagnostik untuk gangguan kecemasan. Psikologi emosi penuh dengan pandangan yang beragam dan berlawanan tentang sifat serta fungsi emosi manusia. Semua ahli teori emosi yang menerima keberadaan emosi dasar, bagaimanapun, menganggap ketakutan sebagai salah satunya (David A. Clark \& Beck, 2010).

Oleh sebab itu, kecemasan perlu penangan khusus agar tidak berdampak pada aspek psikologis yang buruk. Salah satu treatment yang dapat meruduksi kecemasan adalah menggunakan strategi coping yang berkofus pada emosi (emotion focused coping). Penilaian terbukti menjadi prediktor yang kuat apakah koping berorientasi pada regulasi emosi (emotion focused coping) dalam melakukan sesuatu untuk meringankan masalah, serta secara umum, bentuk coping yang berfokus pada emosi (emotion focused coping) lebih mungkin terjadi ketika telah ada persoalan yang tidak dapat dilakukan apa pun dalam memodifikasi kondisi lingkungan yang berbahaya, mengancam, atau menantang. (Richard S. Lazarus \& Susan Folkman, 1984).

Pemaafan dapat digunakan sebagai strategi penanggulangan yang berfokus pada emosi untuk mengurangi reaksi stres terhadap pelanggaran. Penelitian empiris langsung menunjukkan bahwa sikap-memaafkan berkaitan dengan hasil kesehatan dan memediasi proses fisiologis sedemikian rupa untuk mendukung konseptualisasi bahwa sikap-memaafkan adalah strategi penanggulangan yang berfokus pada emosi (emotion focused coping). Memaafkan dapat mempengaruhi kesehatan dengan bekerja melalui dukungan sosial, kualitas hubungan, dan agama (Worthington \& Scherer, 2004).

Strategi yang berfokus pada emosi (emotion focused coping) berusaha mengurangi respons emosional terhadap pemicu stress, sementara strategi yang berfokus pada emosi (juga strategi yang berfokus pada gejala atau menghindar) berkonsentrasi untuk meminimalkan emosi hasil dari masalah. Penelitian terbaru juga membahas coping behavior spesifik mengurangi dan terintegrasi dengan dimensi yang berfokus pada emotion focused coping (Herman \& Tetrick, 2009). 
Strategi koping yang berfokus pada emosi adalah upaya dan bertujuan untuk mengurangi emosi negatif dalam konteks interpersonal yang memicu stress. Pemahaman yang lebih baik tentang pola perkembangan normatif coping yang berfokus pada emosi (emotion focused coping), dan proses perkembangan yang mendasari menimbulkan perubahan normatif (Kopp, 2009).

Oleh sebab itu, melalaui emotion focused coping permasalahan yang dialami individu tidak mampu dihadapi secara objektif, sehingga memunculkan kecemasan yang berlebiahan. Berbagai bentuk reaksi negatif yang ditimbulkan kecemasan dapat dilakukan intervensi dengan mengubah bentuk coping behavior yang berdampak pada tereduksinya kecemasan yang memberikan dampak postif bagi kehidupan individu. Seperti yang penulis jelaskan di atas, bahwa setiap individu pada dasarnya memiliki coping ability. Dinamika dan pengaplikasian dari coping ability tersebutlah yang merupakan cerminan diri individu secara utuh. Gatra dan kondisi pacadaya yang paling awal setiap individu, sesuai dengan fitrahnya adalah baik. Akan tetapi pengembangannya yang menjadikan kurang optimal dalam proses perwujudan individu seutuhnya. Pengembangan yang kurang optimal inilah yang menimbulkan berbagai permasalahan, termasuk di dalamnya kecemasan. Untuk itu denga adanya pengembangan yang optimal melalui konseling dengn memperkuat coping ability yang berfokus pada emosi (emotion focused coping) yang memfokuskan pengembangan diri. Sehingga menghasilkan tingkah laku yang positif dan terarah kepada kehidupan efektif sehari-hari.

\section{KESIMPULAN}

Pada hakiatnya emotion focused coping mampu memberikan warna baru terhadap penanganan kecemasan yang dirasakan individu pada masa pandemic covid-19. Melalui emotion focused coping berusaha mengurangi respons emosional terhadap pemicu stress, dan berkonsentrasi untuk meminimalkan emosi hasil dari masalah. Melalui terapi doa, dzikir, dan sembari memusatkan perhatian kepada hal-hal positif akan berdampak pada regulasi diri yang baik.Sehingga membentuk coping ability dan tereduksinya kecemasan yang dirasakan pada masa pandemi covid-19. 


\section{DAFTAR PUSTAKA}

Carl F. Weems, \& W. S. 2013. Child and Adolescent Psychopathology. In Theodore P. Beauchaine \& Stephen P. Hinshaw (Ed.), Oxford University Press (Second Edi). https://doi.org/10.1055/a-0959-0722

David A. Clark, \&, \& Beck, A. T. 2010. Cognitive Therapy of Anxiety Disorders. New York: The Guilford Press.

Herman, J. L., \& Tetrick, L. E. 2009. PROBLEM-FOCUSED VERSUS EMOTION-FOCUSED COPING STRATEGIES AND REPATRIATION ADJUSTMENT. 48(1), 69-88. https://doi.org/10.1002/hrm

Jiang, L., Broome, M. E., \& Ning, C. 2020. The performance and professionalism of nurses in the fight against the new outbreak of COVID-19 epidemic of Chinese nurses is laudable. International Journal of Nursing Studies, (PG103578-103578), 103578. https://doi.org/https://doi.org/10.1016/j.ijnurstu.2020.103578

Kehoe, W. A. 2017. Generalized Anxiety Disorder. In ASCAP. https://doi.org/10.1093/med/9780199937905.003.0002

Kopp, C. B. 2009. Emotion-Focused Coping in Young Children: Self and SelfRegulatory Processes. (124), 33-46. https://doi.org/10.1002/cd

Maina, G., Mauri, M., \& Rossi, A. 2016. Anxiety and depression. Journal of Psychopathology, $22(4)$,
https://doi.org/10.5005/jp/books/18030_26

Martin, P. 2003. The epidemiology of anxiety disorders: A review. Dialogues in Clinical Neuroscience, 5(3), 281-298.

Mazza, M. G., De Lorenzo, R., Conte, C., Poletti, S., Vai, B., Bollettini, I., ... Benedetti, F. 2020. Anxiety and depression in COVID-19 survivors: Role of inflammatory and clinical predictors. Brain, Behavior, and Immunity, 89, 594-600. https://doi.org/https://doi.org/10.1016/j.bbi.2020.07.037

Nikčević, A. V, Marino, C., Kolubinski, D. C., Leach, D., \& Spada, M. M. 2021. Modelling the contribution of the Big Five personality traits, health anxiety, and COVID-19 psychological distress to generalised anxiety and depressive symptoms during the COVID-19 pandemic. Journal of Affective Disorders, 279, 578-584. https://doi.org/https://doi.org/10.1016/j.jad.2020.10.053

Putri, R. N. 2020. Indonesia dalam Menghadapi Pandemi Covid-19. Jurnal Ilmiah $\begin{array}{llll}\text { Universitas Batanghari Jambi, } & \text { 20(2), }\end{array}$ https://doi.org/10.33087/jiubj.v20i2.1010

Rector, N. A., Bourdeau, D., Kitchen, K., \& Massiah, L. J. 2011. Anxiety Disorders an Information Guide. Canada: Centre for Addiction and Mental Health. 
Richard S. Lazarus \& Susan Folkman. 1984. Stress, Appraisal, and Coping. New York: Springer Publishing Company, Inc.

Roy, D., Tripathy, S., Kar, S. K., Sharma, N., Verma, S. K., \& Kaushal, V. 2020. Study of knowledge, attitude, anxiety \& perceived mental healthcare need in Indian population during COVID-19 pandemic. Asian Journal of Psychiatry, 51, 102083. https://doi.org/https://doi.org/10.1016/j.ajp.2020.102083

Sohrabi, C., Alsafi, Z., O’Neill, N., Khan, M., Kerwan, A., Al-Jabir, A., Agha, R. 2020. World Health Organization declares global emergency: A review of the 2019 novel coronavirus (COVID-19). International Journal of Surgery, 76(February), 71-76. https://doi.org/10.1016/j.ijsu.2020.02.034

Sujadi, E., Kamil, D., Ds, M. R., Yandri, H., Juliawati, D., \& Fadhli, Muhammad., S. I. 2020. Does COVID-19 Significantly Affect the Quality of Life? The Impact Analysis of Does COVID-19 Significantly Affect the Quality of Life? The Impact Analysis of COVID-19 on Work, Financial, Quality of Worship, Emotional and Social Aspects. (October).

Syah, R. H. 2020. Dampak Covid-19 pada Pendidikan di Indonesia: Sekolah, Keterampilan, dan Proses Pembelajaran. SALAM: Jurnal Sosial Dan Budaya Syar-I, 7(5). https://doi.org/10.15408/sjsbs.v7i5.15314

Syaiful Indra, N. A. 2016. Implementasi Konseling Psikoanalisis untuk Mengurangi Kecemasan. In Tamsil Muis (Ed.), Seminar Nasional Bimbingan Konseling (Pengembangan Profesi Bimbingan dan Konseling) (pp. 432438). Surabaya.

Ulya, H. N. 2020. Alternatif Strategi Penanganan Dampak Ekonomi Covid-19 Pemerintah Daerah Jawa Timur Pada Kawasan Agropolitan. El-Barka: Journal of Islamic Economics and Business, 3(1), 80-109. https://doi.org/10.21154/elbarka.v3i1.2018

Wong, Paul T. P., L. C. J. W. 2006. Hand Book of Multicultural Perspectives on Stress and Coping (A. J. Marsela, ed.). New York: Springer Science Business Media, Inc.

Worthington, E. L., \& Scherer, M. 2004. Forgiveness is an emotion-focused coping strategy that can reduce health risks and promote health resilience: theory, review, and hypotheses. Psychology \& Health, 19(3), 385-405. https://doi.org/10.1080/0887044042000196674 